James Alexander, 'Imitatio Pilati et Christi in Modern Historical Drama', in The Edinburgh Compasion to the Bible and the Arts ed. Stephen Prickett (Edinburgh University Press, 2014). ISBN-10: 0748639330. ISBN-13: 978-0748639335 This chapter, written at the invitation of Stephen Prickett, enabled me to return to many essays I wrote on modern historical drama after 2000. I intended at the time to write a book on this subject, but this chapter is as far as I have got.]

\title{
Imitatio Pilati et Christi in Modern Historical Drama
}

\author{
JAMES ALEXANDER
}

'It is all endless crucifixion.'

There is no simpler dramatic conflict in the history of the world than that between Pilate and Christ. One represents the Emperor, State, exousiai, 'the kingdom of this world', the other represents God, Church, ekklesia, 'the kingdom not of this world'. One, the embodiment of authority; the other, the embodiment of truth. ${ }^{2}$ It is the intention of this chapter to demonstrate that this dramatic conflict is the original of almost all the conflict set on the stage in modern historical drama - that is, the historical drama written and staged in the last few centuries.

Historical drama is not usually treated as a major form of literature. ${ }^{3}$ It is usually held that Ionescan or Brechtian drama or some -

\footnotetext{
${ }^{1}$ Ronald Duncan, Stratton (London: Faber and Faber), Act 4, p. 158.

${ }^{2}$ For the exchanges between Pilate and Christ, see (i) Matt. 27.11-14 = Mark 15.2-5 = Luke 23.2-4, (ii) John 18.33-38, (iii) John 19.9-12, see A Synopsis of the Gospels ed. H.F.D. Sparks (London: A. \& C. Black, 1970-74), Part I, p. 218, Part II, pp. 70, 71 \& 73.

3 The established literature on historical drama tends to lack historical and philosophical depth and so cannot explain its importance. See Herbert Lindenberger, Historical Drama: The Relation of Literature and Reality (Chicago: The University of Chicago Press, 1975), Matthew Wikander, The Play of Truth and State: Historical Drama from Shakespeare to Brecht (Baltimore: John Hopkins University Press, 1986), Niloufer
} 
usually spontaneous or violent or rancorous - compromise between the two is the most important form of modern drama. This is a mistake. The most important form of modern drama is historical drama. Szondi, in Theory of the Modern Drama, declared that there is 'no true historical drama'. ${ }^{4}$ But this was because he mistakenly defined drama as a world sufficient to itself, as something which is not 'a (secondary) representation of something else (primary)' but which 'presents itself, is itself. ${ }^{5}$ On the contrary, drama postulates the existence of two worlds:

1. the world of the actors, the onstage world, and

2. the world of the spectators, the offstage world.

Drama cannot exist without these two worlds. Historical drama distinguishes them clearly since the offstage world is of the present while the onstage world is of the past - although of course the past depicted onstage is supposed to be the past of the offstage world. Lukács said rightly that in historical drama 'we have to experience a happening of long ago as if it is actually taking place in the present and has direct reference to the present. ${ }^{6}$ It is both a representation of past events and a presentation of present events. And this is only one of the complications.

The subject of this chapter is a tangled one. It is neither possible to define drama simply when there is a history of drama, nor possible to define historical drama simply when there is a history of historical drama. But in order to be able to make sense of this subject some simplification is necessary. First, it must be observed that almost all great drama in modernity, whether historical or not, has been tragic in one sense or other. Tragedy is a famously confusing subject, but it can be simplified. Balthasar distinguished three types of tragedy:

1. tragedy which ends in reconciliation onstage,

Harben, Twentieth-Century English History Plays: From Shaw to Bond (London: Macmillan, 1988) and D. Keith Peacock Radical stages: alternative history in modern British drama (New York: Greenwood Press, 1991).

${ }^{4}$ Peter Szondi, 'The Drama' in Theory of the Modern Drama ed. Michael Hayes (University of Minnesota Press: Minneapolis, 1965), p. 51.

${ }^{5}$ Ibid., pp. 7-10.

${ }^{6}$ Georg Lukács, The Historical Novel trans. Hannah and Stanley Mitchell (London: Merlin Press, 1962), p. 152. 
2. tragedy which does not end in reconciliation onstage but points to a reconciliation offstage, and

3. tragedy which neither ends in reconciliation onstage or offstage. ${ }^{7}$

There is, of course, as he did not see - because he did not distinguish the two worlds of drama, onstage and offstage - a fourth possibility:

4. tragedy which ends in reconciliation onstage, and yet indicates that there is no reconciliation offstage.

We can see from this that there are two absolute ends of tragedy. One is Hegel's, which is reconciliation. The other is Schopenhauer's, which is resignation. Hegel and Schopenhauer were, of course, philosophers concerned to understood tragedy in terms of our entire experience. There can be no compromise between their theories of tragedy, because they depend on opposite theories about the truth of the world. For Hegel tragedy is a sacrifice for sin, whereby the individual who brings disorder into the world is destroyed so that order may be restored in the world. ${ }^{8}$ And for Schopenhauer tragedy is an awakening to suffering, whereby the individual comes to know the suffering of the world by experiencing that suffering himself. For Hegel, action is justified; whereas, for Schopenhauer, only passion is justified. Hegel supposes that tragedy points to eternal order, so reconciliation is redemption; whereas Schopenhauer supposes that tragedy points only to eternal disorder, so resignation is redemption. ${ }^{9}$

These two views of tragedy depend on different views about truth. The former insists on a reconciliatory truth that can overcome sin and suffering, while the latter denies any such truth, so that its truth, so to speak, is the truth that there is no truth (at least no truth in the sense of a reconciliatory truth): there is only the truth of a resignatory truth, whatever that is. These two truths, which of course are not equal and opposite, nonetheless state the extreme possibilities of what can be

\footnotetext{
${ }^{7}$ For the threefold, which he derived from Lesky, see Hans Urs von Balthasar, TheoDrama: Theological Dramatic Theory Vol. 1: Prolegomena trans. Graham Harrison (San Francisco: St Ignatius Press, 1988), pp. 425-6.

${ }^{8}$ G.W.F. Hegel, Aesthetics: Lectures on Fine Art trans. T.M. Knox (Oxford: Clarendon Press, 1975) Vol. 2, pp. 1197-8.

${ }^{9}$ Arthur Schopenhauer, The World As Will and Representation trans. E.F.J. Payne (New York: Dover, 1969), Vol. 1, p. 253.
} 
understood by us either onstage or offstage. ${ }^{10}$ There are of course many other, relative truths, even down to subjective truths, which may also be evident onstage or offstage, but these two can be taken to establish the outer limits of what can be true. They are:

1. the truth of 'crucifixion-resurrection', and

2. the truth that 'there is no such truth'.

These two truths are completely asymmetrical. The difference between them is the difference between a singularity and infinite space. The truth of 'crucifixion-resurrection' is not an abstraction, but a particular, which is also, interestingly, a universal. ${ }^{11}$ There are many other reconciliatory truths, offered by other religions: but this truth is perhaps the perfect form of a reconciliatory truth, for the reason that it is not only a truth but also an event. It is therefore of dramatic and historical significance. It makes history significant in a way that the truth that 'there is no truth' cannot, because it is a point of rupture in history. It postulates the existence of two worlds, a lower world and a higher world, which of course are analogous to the two worlds, onstage and offstage, of the drama. If God exists there is always 'a play within the play: our play "plays" in his play." ${ }^{, 2}$ Christ crucified is perhaps an absurdity - 'It is absurd', said Tertullian, 'so I believe it' - but it is an absurdity which has run like a red thread through modern historical drama. The second truth, by contrast, postulates the existence of only one world. It is hard to find a simple formulation for this truth, since - as Nagarjuna showed - all attempts to state it as a truth lead to paradox. It could be restated as 'everything is empty' (in relation to meaning) or 'everything is suffering' (in relation to action) or something similar, but in the form 'there is no such truth' we can certainly see that it involves the denial of truths like the truth of 'crucifixion-resurrection', and is, whatever it is as a position in its own terms, a negation of that position. If it claims 'there is no truth' in relation to its own truth, it may also be a paradox, but one establishes the further limit of what is possible in tragedy. As such it is the truth which lies behind most modern drama which is not historical.

\footnotetext{
${ }^{10}$ For more on this see James Alexander, 'The Four Points of the Compass', Philosophy 87 (2012), pp. 79-107.

${ }^{11}$ As Michael Ramsey put it, 'The centre of Apostolic Christianity is CrucifixionResurrection.' The Resurrection of Christ: An Essay in Biblical Theology (London: Geoffrey Bless, 1955), p. 19.

12 Balthasar, Theo-Drama, p. 20.
} 
This modern drama - the famous drama of Chekhov, Pirandello, Brecht, Ionesco and Beckett - is godless. The Oresteia had many gods, Everyman one God, Waiting for Godot no gods. A drama without gods is a drama of resignation, not a drama of reconciliation. And it has had perhaps two major forms, which we could call Ionescan and Brechtian. In Ionescan drama all events are disrupted by the realisation that there is no truth. In Brechtian drama all truth is disrupted by the continuing struggle to survive events. As Balthasar put it, Ionesco's drama is wholly vertical, concerned with the eternal, Brecht's wholly horizontal, concerned with the temporal: but they are mirrors of each other, in that each grasps one half of the truth. ${ }^{13}$ Ionesco treats solitude tragically, and Brecht treats solidarity tragically. They are both unaware that there are 'two simultaneous sorrows, solitude and solidarity'. ${ }^{14}$ But both depict the emptiness of existence. In them drama destroys itself and leaves behind only theatre, or what is sometimes called 'theatricality' - a world in which events may or not be broken by interruptions which make no sense in terms of those events. ${ }^{15} \mathrm{We}$ could say that theatricality is the embodiment on the stage of Schopenhauerian acceptance of - or, more likely, Nietzschean exultation in - the tragedy of the emptiness of existence. There is no logos, only doxa. There are no hierarchies, only an equality of angst. There are no truths, only the truth that there is no truth. There is no death, only the end of life - or the living of life as if it is a death.

If modern drama is the consequence of the loss of the truth of 'crucifixion-resurrection', then modern historical drama is the form of drama which emerged alongside it to put 'crucifixion-resurrection' onstage: not directly, but indirectly - historically. Acton once said that we write history out of loss. And this means that although a historical consciousness may tell us that truths are temporal and not eternal, and thus separate us from the past, this same historical consciousness may be a means by which we restore the past to the present. Just as modern drama in both its forms arose to depict our experience of loss - the loss of the truth of 'crucifixion-resurrection' - so modern historical drama arose to overcome the loss of this truth offstage by putting it onstage so it could be considered. Of course historical drama is at least as old as Shakespeare, but what I call modern historical drama is distinctive for

\footnotetext{
${ }^{13}$ Ibid., p. 344.

14 The quotation is from Griffin, The Hidden King, p. 178, cited below in note 41.

${ }^{15}$ See, for instance, Tracy C. Davis ed. Theatricality (Cambridge: Cambridge University Press, 2010).
} 
the reason that it is concerned with truth. In order to make this clear, it is necessary to distinguish three eras of historical drama in terms of shifts in historical consciousness since the Reformation:

1. PREMODERN HISTORICAL DRAMA, in which past and present are united in the truth of 'crucifixionresurrection', which is so much taken for granted offstage that it need not be dramatised onstage or, for reasons of censorship, cannot be dramatised onstage;

2. MODERN HISTORICAL DRAMA, in which past and present are separated because the truth of 'crucifixion-resurrection' is doubted in the present, so that the past in which this truth was considered true is now put onstage, so that its truth can be dramatised, and thus considered offstage in the present; and

3. POSTMODERN HISTORICAL DRAMA, in which past and present are separated by the certainty that the truth of 'crucifixion-resurrection' is not true at all, so that the past in which it was taken to be true can no longer be dramatised but only theatrically put on display as a curiosity.

The first is a drama of belief, the second a drama of doubt, and the third a drama of unbelief. In the broadest possible sense, they form a historical succession, but in fact, as is usually the case in literature, they have existed alongside each other for long periods, and echoes are heard across them. The obvious way to distinguish them is in terms of how they develop action. The first usually depends on plot to further the action, the famous resources of intrigue and accident, of conspiracy, intercepted letters, mistaken identity and so on. Hegel said that drama depicts 'collisions of circumstances, passions and characters'. ${ }^{16}$ But in the second, conflict is not only of circumstances, passions and characters: it is also a conflict about the truth, this truth of 'crucifixionresurrection' and how it is manifest in the world. It depends on argument to further the action. The third depends on neither plot nor

\footnotetext{
${ }^{16}$ Hegel, Aesthetics, Vol. 2, p. 1159. For the tendentious suggestion that the collisions are always 'social collisions', see Lukács, The Historical Novel, p. 98.
} 
argument to further the action, but only on what is theatrically effective. The first is usually written in poetry, the second in prose, and the third in speech. The second is the most remarkable in terms of content because of its dramatisation of argument about truth. The first ignores every truth except the truth of the dramatic situation; while the third is a consequence of the interruption of Ionescan and Brechtian models into the historical drama and tends to mock any truth except some existential or socialist truth which is supposed by the dramatist to fill the void. Perfect instances of premodern drama are Schiller's The Maid of Orleans and Tennyson's Becket, perfect instances of modern historical drama are Ibsen's Emperor and Galilean, Shaw's Saint Joan and Eliot's Murder in the Cathedral; and perfect instances of postmodern historical drama are Bond's Early Morning, Brenton's Romans in Britain and Barnes's Sunsets and Glories.

It is important to note that modern historical drama does not consider 'crucifixion-resurrection' directly. That cannot be done except within the church. Modern historical drama in fact occupies a position of centrality between premodern reverence and postmodern irreverence. It was written during the period when censorship laws meant the event of 'crucifixion-resurrection' could not be put on stage - but this was not a problem, since this drama is impossible to stage. There were a few attempts in the last century to put it onstage, but only ever with Judas or Mary Magdalene as the protagonist, with Jesus speaking offstage or silent onstage. ${ }^{17}$ Shaw once argued that the reason that the trial of Jesus could not be dramatised was because he did not say much to Pilate. ${ }^{18}$ The reason is in fact is that the encounter is not an encounter between equals. It cannot be brought into the symmetry modern drama requires, since Pilate does not recognise the truth. He does not understand the

\footnotetext{
${ }^{17}$ Christ was offstage in Maurice Maeterlinck, Mary Magdalene: A Play in Three Acts trans. Alexander Teixeira de Mattos (London: Methuen, 1910) and E. Temple Thurston, Judas Iscariot: A Play in Four Acts (London: G.P. Putnam's Sons, 1923); he was onstage but not centre stage in W.B. Yeats, Cavalry (1920) in The Collected Plays of W.B. Yeats (London: Macmillan, 1953), pp. 449-57, John Masefield, The Trial of Jesus (London: William Heinemann, 1925), and Charles Williams, The Three Temptations in Collected Plays (London: Oxford University Press, 1963); and centre stage, with diminishing returns, in Dorothy L. Sayers's stiff The Man Born To Be King: A Play-Cycle on the Life of Our Lord and Saviour Jesus Christ (London: Victor Gollancz, 1943), Dennis Potter's slack Son of Man (Harmondsworth, Penguin, 1971) and Edwin Morgan's sloppy AD: A Trilogy of Plays on the Life of Jesus (Manchester: Carcanet, 2000).

18 George Bernard Shaw, The Complete Prefaces ed. D.H. Laurence and D.J. O'Leary (London: Penguin, 1997), Vol. III, p. 203.
} 
distinction between the 'kingdom of this world' and the 'kingdom not of this world', so there can be no argument. As an event 'crucifixionresurrection' cannot be put on the stage without reverence or irreverence because it involves resurrection. ${ }^{19}$ Since modern historical drama is neither reverent nor irreverent, it cannot depict resurrection.

Modern historical drama accordingly approaches 'crucifixionresurrection' through indirection. Since it is both truth and event, it can be approached in two ways. Modern historical drama is drama in which 'crucifixion-resurrection' is either

1. an accepted truth or

2. an exemplary event

or, as it often is, both. If it is an accepted truth, this means that the drama concerns a historical situation in which the truth of 'crucifixionresurrection' at least partly conditions the action - which means any historical situation taken from the history of Christianity and Christendom. If it is an exemplary event, this means that the drama is an imitation of the event of 'crucifixion-resurrection' on its shadow side, or secular side, that is, as mere crucifixion: which of course includes the events which lead to crucifixion, that is to say, temptation and trial. Usually modern historical drama alludes to both truth and event, by taking an event from the history of Christianity which somehow enables the truth of Christianity to be restored - onstage, in the past, and therefore offstage, in the present. The particular historical subjects which in either or both of these ways derive from the exemplary drama - truth and event - of 'crucifixion-resurrection' are extremely varied. But they usually concern 'world-historical figures': that is, figures whose acts have great significance, actual or exemplary, for the rest of the world - kings and captives, saints and sinners. They rarely concern ordinary men and women, and when they do, this is usually because the tragedy is resignatory rather than reconciliatory, epic rather than

\footnotetext{
${ }^{19}$ For reverence about resurrection see Kaj Munk, The Word (1925) in Five Plays trans. R.P. Keigwin (New York: The American-Scandinavian Foundation, 1953), and Paul Claudel, The Tidings Brought to Mary: A Drama trans. Wallace Fowlie (Chicago: Regnery, 1960). For irreverence see Peter Barnes, Leonardo's Last Supper (1969) in Plays 1 (London: Methuen, 1994) and The Spirit of Man (1982) in Plays 2 (London: Methuen, 1996).
} 
dramatic, and hence tends to the postmodern. ${ }^{20}$ They usually concern the conflicts in which these major historical figures come into conflict over the possibility that one or other will be crucified, actually, or even symbolically. The crucifixion may be an actual death, but it may also be the avoidance of death.

Tragedy in modern historical drama is ambivalent, because the truth on which our understanding of tragedy depends is put in question in this form of drama. ${ }^{21}$ If we say a tragedy always involves the destruction of someone, then there is a scale of tragedy:

1. tragedy in which a man is destroyed accidentally which gives us the modern newspaper sense of the word 'tragedy';

2. tragedy in which a man is deliberately destroyed by other men;

3. tragedy in which a man is deliberately destroyed by the gods, or, in modern drama, as if by the gods (as a consequence of external fate or internal flaw);

4. tragedy in which a god is deliberately destroyed by other gods, as Osiris was; and

5. tragedy in which God is destroyed - so that 'God is dead!' (as Proctor says in The Crucible and Goetz says in Lucifer and the Lord) - and destroyed, as is inevitable, by man.

This last possibility is so strange that it is with good reason that Paul called it a skandolon, a scandal - 'unto the Jews a stumbling-block, and unto the Greeks a foolishness'. ${ }^{23}$ The entirety of Christian theology was an attempt to make sense of it. Since God could not destroy himself in his own world, he allowed himself to be destroyed in our world, as someone of our world, as a man. He submitted himself to trial and

${ }^{20}$ Lukács observes rightly that whereas the historical novel makes minor figures central, historical drama almost always makes major figures central. See The Historical Novel, p. 103. The exceptions are interesting: Miller's Crucible, Churchill's Light Shining in Buckinghamshire and so on, but still rare.

${ }^{21}$ For general reflections on tragedy see A.D. Nuttall, Why Does Tragedy Give Pleasure? (Oxford: Clarendon Press, 1996) and Ian Robinson, 'Christian Tragedy: King Lear and Bleak House, unpublished MS.

22 See Raymond Williams, Modern Tragedy (Stanford: Stanford University Press, 1966) for a Marxist attempt to relate the 'tragedy of our time' to dramatic tragedy.

231 Corinthians 1.23 . 
judgement by men, and thus became the ultimate tragos. ${ }^{24}$ If 'crucifixionresurrection' is the truth, then there is no abstraction behind the particular: the particular is the original, and everything derives from it. And the possibility that this is true has to exist on the stage so that history can exist there. Christ did not have the truth, but was the truth 'the way, the truth and the life' - and so in sacrificing himself for our sins was going so far beyond what was previously possible in tragedy that all tragedy afterwards was influenced by it. ${ }^{25}$ If he was not the truth, then, of course, the crucifixion is just one more tragedy to be lamented along with all the others. But it is doubt about this truth, and doubt about what should be done about it in this world, which is constitutive of all modern historical drama.

Modern historical drama brings certainties into conflict by embodying them in characters, one of whom is a king of this world and one of whom is a king not of this world. It is the great literature of imitatio Pilati et Christi. There is conflict, as there is in all drama. But here the conflict is asymmetrical, because it involves truth: and this is another reason why such drama must be historical. Most modern drama since Chekhov, Pirandello, Beckett and the rest has difficulty in dealing with hierarchies of status - and therefore finds tragedy difficult. Schopenhauer mordantly observed in the nineteenth century 'bourgeois characters lack the height from which to fall. ${ }^{26}$ And even Lukács admitted a century later that 'most bourgeois and, unfortunately, most proletarian plays are banal, tedious and insignificant. ${ }^{27}$ But modern

\footnotetext{
${ }^{24}$ The blood of Christ is compared to the blood of goats in Hebrews 10.4. The word 'tragedy' comes from the Greek word for goat. See W.W. Skeat, Concise Etymological Dictionary of the English Language $4^{\text {th }}$ ed. (Oxford: Clarendon, 1894), p. 519, and Chambers Dictionary of Etymology ed. R.K. Barnhart (Edinburgh: Chambers, 1988), p. 1157, for opposite explanations of its origin. Skeat claims tragedy has something to do with sacrifice, as does Christopher Booker in his magnificent The Seven Basic Plots: Why We Read Stories (London: Continuum, 2004), p. 620 n. 17.

${ }^{25}$ Critics in the last century tended to be Schopenhauerian (like Nietzsche in The Birth of Tragedy) and so disagreed. 'It is doubtful whether the sense of tragedy is compatible with belief in God.' George Orwell, 'Lear, Tolstoy and the Fool' (1947) in The Collected Essays, Journalism and Letters (Harmondsworth: Penguin, 1970), Vol. 4, p. 338. 'Only if the divine order can be questioned is there tragedy: if not, if there is only sin and repentance, then there is no tragedy.' Albert Camus, 'The Future of Tragedy', Selected Essays and Notebooks ed. Philip Thody (Harmondsworth: Penguin, 1979), pp. 192-203, at p. 197. 'Christianity is an anti-tragic vision of the world.' George Steiner, The Death of Tragedy (London: Faber and Faber, 1963), pp. 339.

${ }^{26}$ Schopenhauer, The World as Will and Representation, p. 437.

${ }^{27}$ Lukács, The Historical Novel, p. 105.
} 
historical drama, which dramatises men and women of the highest and lowest status, enables us to reflect on the ancient and profound question of who is the true king. ${ }^{28}$ Since Christ and the possibility that the true king is not a king of this world, the asymmetrical conflict between the vicarius Pilati and the vicarius Christi is always in principle one in which the truths of the world can be put in question by another truth.

The encounter between the vicarius Pilati and the vicarius Christi is not the same as the encounter between Pilate and Christ. Christ was the truth; Pilate did not understand the truth. But the vicarius Pilati and the vicarius Christi differ from the originals: the former because he may understand the truth; and the latter because he is not the truth. So we see, again and again, flawed crucifixions and failed martyrdoms: in which a corrupt vicarius Pilati who knows the truth has a flawed vicarius Christi condemned for a truth which the vicarius Pilati, unlike Pilate, knows and which the vicarius Christi, unlike Christ, cannot embody. Almost all modern historical plays, and some premodern and postmodern plays in which there are echoes of this modern subject, can be categorised in relation to whether the vicarius Christi is martyred, murdered and not martyred, or neither martyred nor murdered. Martyrdom is death for a truth, or, in some cases, dying to life; and murder is mere death, the end of life. The vicarius Christi is martyred in the following plays (dated by first performance):

$$
\begin{aligned}
& \text { Schiller's Mary Stuart (1800), }{ }^{29} \text { Schiller's The Maid of } \\
& \text { Orleans (1801), }{ }^{30} \text { Büchner's Danton's Death (1835), }{ }^{31} \\
& \text { Tennyson's Becket (1884), }{ }^{32} \text { Shaw's Saint Joan (1924), }
\end{aligned}
$$

\footnotetext{
${ }^{28}$ This question has existed at least since the Old Testament. See 1 Samuel 10.1 and Judges 8.22-23 for the paradigmatic events. And for an analysis see Martin Buber, Kingship of God trans. Richard Scheimann (New York: Harper and Row, 1967). Many modern Old Testament plays deal with this problem in a way that excludes Christ. See D.H. Lawrence David (1926) in The Plays ed. Hans-Wilhelm Schwarze and John Worthen (Cambridge: Cambridge University Press, 1999), Laurence Housman, 'Samuel the Kingmaker' (1944) in Old Testament Plays (London: Jonathan Cape, 1950), Christopher Fry, The Firstborn: A Play in Three Acts (London: Oxford University Press, 1958), and Peter Shaffer, Yonadab (1985) (Harmondsworth: Penguin, 1989). But so did Racine in Athaliah: A Tragedy (1691). And Shakespeare in the histories.

${ }^{29}$ Friedrich Schiller, Mary Stuart trans. F.J. Lamport (Harmondsworth: Penguin, 1998).

${ }^{30}$ Friedrich Schiller, Maid of Orleans trans. Major-General Maxwell (London: W. Scott, 1892).

31 George Büchner, Danton's Death in The Plays of George Büchner trans. Victor Paris

(Oxford University Press, 1971).

32 Alfred Lord Tennyson, Becket (London: Macmillan, 1884).
} 
Eliot's Murder in the Cathedral (1935), ${ }^{34}$ Williams's Thomas Cranmer of Canterbury (1936), ${ }^{35}$ Duncan's This Way to the Tomb (1946), ${ }^{36}$ Montherlant's Master of Santiago (1947), ${ }^{37}$ Anouilh's The Lark (1952), ${ }^{38}$ Miller's Crucible (1953), ${ }^{39}$ Chiari's Mary Stuart (1954), ${ }^{40}$ Griffin's Hidden King (1955), ${ }^{41}$ Anouilh's Becket or the Honour of God (1959), ${ }^{42}$ Bolt's $A$ Man For All Seasons (1960), ${ }^{43}$ Whiting's The Devils (1961), ${ }^{44}$ Fry's Curtmantle (1962), ${ }^{45}$ Bolt's Vivat! Vivat Regina! (1970), ${ }^{46}$ Campbell's The Jesuit (1976), ${ }^{47}$ Barnes's Sunsets and Glories (1990), ${ }^{48}$ Brenton's Anne Boleyn (2011). ${ }^{49}$

The vicarius Christi is not martyred but murdered in:

Ibsen's Emperor and Galilean (1873), ${ }^{50}$ Camus's Caligula (1944), ${ }^{51}$ Shaffer's The Royal Hunt of the Sun (1964), ${ }^{52}$

\footnotetext{
${ }^{33}$ Bernard Shaw, Saint Joan: A Chronicle Play (London: Constable, 1924).

34 T.S. Eliot, Murder in the Cathedral (London: Faber and Faber, 1938).

${ }^{35}$ Charles Williams, Thomas Cranmer of Canterbury in Williams, Collected Plays.

${ }^{36}$ Ronald Duncan, This Way to the Tomb: $A$ Masque and Anti-Masque (London: Faber and Faber, 1946).

${ }^{37}$ Henry de Montherlant, The Master of Santiago in Montherlant, The Master of Santiago and Four Other Plays trans. Jonathan Griffin (London: Routledge and Kegan Paul, 1951). ${ }^{38}$ Jean Anouilh, The Lark trans. Christopher Fry (London: Methuen, 1955).

${ }^{39}$ Arthur Miller, The Crucible (Harmondsworth: Penguin, 1968).

${ }^{40}$ Joseph Chiari, Mary Stuart: A Verse Play (London: Oxford University Press, 1955).

${ }^{41}$ Jonathan Griffin, The Hidden King: A Poem for the Stage in the Form of a Trilogy (London: Secker and Warburg, 1955).

${ }^{42}$ Jean Anouilh, Becket, or The Honour of God trans. Lucienne Hill (London: Eyre

Methuen, 1961).

${ }^{43}$ Robert Bolt, A Man for All Seasons (London: Heinemann, 1960).

${ }^{44}$ John Whiting, The Devils (London: Heinemann, 1972).

${ }^{45}$ Christopher Fry, Curtmantle in Plays (Oxford: Oxford University Press, 1971).

${ }^{46}$ Robert Bolt, Vivat! Vivat Regina! A Play in Two Acts (London: Heinemann, 1971).

${ }^{47}$ Donald Campbell, The Jesuit (Edinburgh: Paul Harris, 1976).

48 Peter Barnes, Sunsets and Glories (1990) in Barnes, Plays 2.

${ }^{49}$ Howard Brenton, Anne Boleyn (London: Hern, 2011).

${ }^{50}$ Henrik Ibsen, Emperor and Galilean: A World-Historic Drama ed. William Archer (London: Walter Scott, 1906).

${ }^{51}$ Albert Camus, Caligula and Cross Purpose trans. Stuart Gilbert (Harmondsworth: Penguin 1965).

52 Peter Shaffer, The Royal Hunt of the Sun: A Play Concerning the Conquest of Peru (London: Hamish Hamilton, 1964).
} 
Arden's Armstrong's Last Goodnight (1965) ${ }^{53}$ and McGuinness's Innocence (1987). ${ }^{54}$

The vicarius Christi is neither martyred nor murdered but lives on (sometimes in misery) in:

Strindberg's Master Olof (1872), ${ }^{55}$ Sayers's Emperor
Constantine (1951), ${ }^{56}$ Brecht's Life of Galileo (1955), ${ }^{57}$
Bessborough's Triptych (1957), ${ }^{58}$ Osborne's Luther
(1961), ${ }^{59}$ Dickinson's A Durable Fire (1962), ${ }^{60}$ Arden's
Left-Handed Liberty (1965), ${ }^{61}$ Endo's Golden Country
(1966), ${ }^{62}$ Foster's Tom Paine (1967), ${ }^{63}$ Griffiths's
Occupations (1970), ${ }^{64}$ Churchill's Light Shining in
Buckinghamshire (1976), ${ }^{65}$ Wesker's Caritas (1981), ${ }^{66}$ Arden
and D'Arcy's Whose is the Kingdom? (1988), ${ }^{67}$ and
Griffiths's These Are the Times (2005). ${ }^{68}$

And there are other plays in which it is harder to identify a vicarius Christi but in which there is murder and possible martyrdom throughout:

\footnotetext{
${ }^{53}$ John Arden, Armstrong's Last Goodnight: An Exercise in Diplomacy (London: Methuen, 1965).

${ }^{54}$ Frank McGuinness, Innocence: The Life and Death of Michelangelo Merisi, Caravaggio (London: Faber and Faber, 1987).

${ }^{55}$ Strindberg, Master Olof (1872) in The Vasa Trilogy trans. Walter Johnson (SeattleUniversity of Washington Press, 1959).

${ }^{56}$ Dorothy L. Sayers, The Emperor Constantine: A Chronicle (London: Victor Gollancz, 1951).

${ }^{57}$ Bertolt Brecht, The Life of Galileo (London: Methuen, 1963).

58 The Earl of Bessborough's Triptych: Trilogy of the Thirteenth Century (London: Heinemann, 1957).

59 John Osborne, Luther (London: Faber and Faber, 1961).

${ }^{60}$ Patric Dickinson, A Durable Fire: A Play (London: Chatto and Windus, 1962).

${ }^{61}$ John Arden, Left-Handed Liberty: A Play About Magna Carta (London: Methuen, 1965).

${ }^{62}$ Shusako Endo, The Golden Country (London: Peter Owen, 1989).

${ }^{63}$ Paul Foster, Tom Paine (London: Calder and Boyars, 1967).

${ }^{64}$ Trevor Griffiths, Occupations and The Big House (London: Caldor and Boyars, 1972).

${ }^{65}$ Caryl Churchill, Light Shining in Buckinghamshire (London: Hern, 1989).

${ }^{66}$ Arnold Wesker, Caritas in Lady Othello and Other Plays (Harmondsworth: Penguin, 1990).

${ }^{67}$ John Arden and Margaretta D'Arcy, Whose is the Kingdom? (London: Methuen, 1988).

${ }^{68}$ Trevor Griffiths, These Are The Times: A Life of Thomas Paine (Nottingham:

Spokesman, 2005).
} 
Tennyson's Queen Mary (1875), ${ }^{69}$ Munk's Cant (1931), ${ }^{70}$ Montherlant's Queen after Death (1942), ${ }^{71}$ Sartre's Lucifer and the Lord (1951), ${ }^{72}$ Weiss's Marat/Sade (1964), ${ }^{73}$ Arden's Ironband (1965), ${ }^{74}$ Arden and D'Arcy's The Island of the Mighty (1974), ${ }^{75}$ Barnes's Bewitched (1974), ${ }^{76}$ Brenton's Romans in Britain (1980), ${ }^{77}$ Oswald's Augustine's Oak (1999). ${ }^{78}$

In many of these plays there is the suggestion that the vicarius Pilati is also in a sense martyred in life because he understands the truth for which the vicarius Christi was martyred in death. This is less common when the vicarius Pilati is a king like Henry VIII - as in Thomas Cranmer of Canterbury, Cant, A Man For All Seasons and Anne Boleyn. But it is true of Henry II in the Becket plays by Tennyson, Anouilh and Fry, and Elizabeth in the Mary Stuart plays by Schiller, Chiari and Bolt. The encounter between Henry II and Becket is a classic encounter, but perhaps even less remarkable than the one between two Queens, in which one Queen is vicarius Pilati and the other vicarius Christi, one a wife, one a virgin, one Catholic, one Protestant. Schiller, Chiari and Bolt all found ways of putting them both on the stage at the same time - the one scene they were denied by the history itself. In some plays the martyred vicarius Pilati is not a king but a priest. This is true of Cauchon in Saint Joan, Spottiswoode in The Jesuit, the Cardinal in Innocence and some others. Sometimes two churchmen are distinguished, one more worldly, one less worldly, like the Rector and the Bishop in Wesker's Caritas, who respond to martyrdom in contrasting ways, one mirroring

${ }^{69}$ Alfred Tennyson, Queen Mary: A Drama (Boston: Osgood, 1875).

${ }^{70}$ Kaj Munk, Cant: A Play of Henry VIII and Anne Boleyn in Five Plays.

${ }^{71}$ Henry de Montherlant, The Queen after Death or How to Kill Women in his The Master of Santiago and Four Other Plays.

72 Jean-Paul Sartre, Lucifer and the Lord trans. Kitty Black in Three Plays (Harmondsworth, Penguin, 1982).

73 Peter Weiss, The Persecution and Assassination of Marat as performed by the inmates of the Asylum of Charenton under the direction of the Marquis of Sade trans. Geoffrey Skelton and Adrian Mitchell (London: Calder, 1965).

${ }^{74}$ John Arden, Ironhand adapted from Goethe's Goetz von Berlichingen (London: Methuen, 1965).

${ }^{75}$ John Arden and Margaretta D'Arcy, The Island of the Mighty: A Play on a Traditional British Theme in Three Parts (London: Eyre Methuen, 1974).

${ }^{76}$ Peter Barnes, The Bewitched (London: Heinemann, 1974).

${ }^{77}$ Howard Brenton, The Romans in Britain (London: Eyre Methuen, 1980).

78 Peter Oswald, Augustine's Oak (London: Oberon, 1999). 
it, one not. Worldly and unworldly churchmen are contrasted in Pandulph and Langton in Arden's Left-Handed Liberty and Dickinson's In Durable Fire, and in Celestine V and Boniface VIII in Barnes's Sunsets and Glories. But when the vicarius Pilati is unrepentant despite his knowledge of the truth for which the vicarius Christi is martyred we have the great figure of the Grand Inquisitor.

The Grand Inquisitor is a vicarius Pilati who knows Christian truth, and defends the establishment of truth in tradition against any attempt to establish the truth again or enact the event again. Schiller, as far as I know, was the first to depict such a figure, the remarkable Grand Inquisitor, ninety and blind, who in Don Carlos (1787) subjugates not only the King but also the Marquis of Posa, a vicarius Christi who stands for secular liberty. Since Schiller wrote premodern plays, he did not have the Marquis and the Inquisitor meet, as they certainly would have done had he written a century later. ${ }^{79}$ This figure was the original of Dostoevsky's famous Grand Inquisitor in The Brothers Karamazov who put a silent Christ on trial for not giving in to the temptations in the wilderness. ${ }^{80}$ And he is found in many modern historical plays - as the Inquisitor in Saint Joan and The Lark, as Danforth in The Crucible, as Folliot in Becket or the Honour of God, as Wolsey in A Man For All Seasons, as Pandulph in Left-Handed Liberty and In Durable Fire, as Cajetan in Luther, as the Bishop of Poitiers and Richelieu in The Devils, as Pontecarrero in The Bewitched, as Gaetani in Sunsets and Glories, as the Bishop of Norwich in Caritas, and as Firenzuola in The Recantation of Galileo Galilei. The high worldly churchman is one of the great figures of modern literature. In some rare plays this figure is affected by the vicarius Christi as if he is the one being put on trial. This is true of Archbishop Spottiswoode in The Jesuit, and Cardinal Francesco del Monte in Innocence - the former makes it possible for Ogilvie to escape martyrdom if he so chooses, while the latter - like Goetz in Sartre's play, Proctor in Miller's play and the Rector in Wesker's play - loses his faith. Innocence depicts a vicarius Pilati who loses his faith as a consequence of his encounter with the very flawed and tormented vicarius Christi of Caravaggio. It is in fact the Cardinal who is martyred, while Caravaggio is only murdered.

In Saint Joan and A Man For All Seasons there is a trial which leads to martyrdom. But just as trial can occur without martyrdom - as

\footnotetext{
${ }^{79}$ Friedrich von Schiller, Don Carlos (1787), in Two German Drama Classics trans. James Kirkup (Salzburg: University of Salzburg, 1996).

${ }^{80}$ See Richard Crane's dramatic adaptation of Brothers Karamazov (1981) in Russian Plays (London: Oberon, 2011), pp. 44-46.
} 
in Master Olof and Luther and The Life of Galileo - so martyrdom can occur without trial, as it does in Murder in the Cathedral. In the first part of the play Becket is subjected to a temptation even Christ did not face.

TEMPTER. What earthly glory, of king and emperor.

What earthly pride, that is not poverty

Compared with richness of heavenly grandeur?

Seek the way of martyrdom, make yourself the lowest

On earth, to be high in heaven.

'Who are you,' Becket says, 'tempting me with my own desires?' But he is the least flawed vicarius Christi seen in the drama. Elsewhere the flaws of the vicarius Christi are expressed in terms of doubt and fear, in a sense of unworthiness. Joan in Saint Joan, and Ogilvie in The Jesuit fear torture because it might make them forget the truth. Other martyrs are sinners, like Grandier in The Devils, although if there is too much unrepentant sin, as there is with Gilnockie in Armstrong's Last Goodnight and Caravaggio in Innocence, then martyrdom is only murder. The martyrdom of an almost perfect vicarius Christi is shocking, as so for different reasons is the martyrdom of a flawed vicarius Christi: but perhaps nothing is as shocking in this drama as a failure of martyrdom.

There are three remarkable plays in which martyrdom fails catastrophically. The Royal Hunt of the Sun depicts the encounter between a pagan vicarius Christi in the Incan King Atuahallpa and a Christian vicarius Pilati in the Spanish conquistador Pizarro. The effective oddity of the play is that Pizarro confuses Atuahallpa's belief that he cannot die unless the sun his father wills it, with his recollection of Christ's resurrection. Pizarro therefore has Atuahallpa murdered, after having him baptised, and then waits. When there is no resurrection of the king, it is as if both Christianity and paganism have failed. The Golden Country depicts the torture of Ferreira, the only priest in Japan, by Japanese officials. 'I am for you the Church,' he says to his flock, but admits to himself, 'I am not Christ'. He cannot withstand torture and so apostatises, and after his trial he is forced to become a vicarius Pilati and put Christians on trial. Caritas depicts the walling up of an anchoress after a ritual of dedication to Christ, which is followed by her loss of faith and descent into a horror of madness and meaninglessness as she addresses an absent God. Here the irony is that the vicarius Christi is martyred for a truth she no longer believes. 
Another variation is evident in what was perhaps the first modern historical play, Emperor and Galilean. Here the Emperor Julian attempts to found a 'third empire' on 'the tree of knowledge and the tree of the cross together' so he can become both 'Emperor and Redeemer' - both vicarius Pilati and vicarius Christi. He fails. 'Woe, woe to the new Pilate!' cries a Christian. 'He is not content, like the first, with slaying the Saviour's body. He murders the word and the faith!' Ironically Julian is murdered by a Christian. Like many plays which deal with a solitary will, either that of a martyr - in This Way to the Tomb and Caritas - or that of an emperor - in Caligula and Whose is the Kingdom? - there is a problem about how to make drama out of an essentially lyric situation. Camus depicted Caligula imagining himself as a sort of Christ, who wants 'something which isn't of this world'. His language is that of a vicarius Christi. 'I shall be transfigured and the world renewed; then men will die no more and at last be happy.' But since he is a vicarius Pilati, and there is only one will, his will, in the world, he ends murdered and not martyred. Usually the problem of how to create drama in a situation in which there is no clear encounter between a vicarius Christi and a vicarius Pilati is to place the lyric subject against an epic background - which is what happens in Emperor and Galilean, Caritas and other plays such as Lucifer and the Lord.

The best way to make sense of the variations sketched here is to categorise the plays historically in terms of their subjects. The history which modern historical drama puts on the stage is one in which the conflict between vicarius Christi and vicarius Pilati has varied according to how the truth of 'crucifixion-resurrection' has existed in the world. At first there was a boundary between the 'kingdom of this world' and the 'kingdom not of this world', but with the incorporation of Christianity into the Roman Empire by Constantine - dramatised in Emperor Constantine and Whose is the Kingdom? - the two kingdoms were increasingly tangled up together. Five forms, or eras, of historical drama can be distinguished:

1. MARTYR DRAMA, in which the vicarius Christi is the truth of 'crucifixion-resurrection' itself, or, we could say, the Holy Spirit, as received by a martyr, and in which the vicarius Pilati is all the world, so the conflict is between faith and lack of faith; 
2. CONVERSION DRAMA, which follows the incorporation of Christianity into the Roman empire, in which the vicarius Christi is the Christian empire and the vicarius Pilati the pagan world, so the conflict is between Christianity and another religion;

3. CATHOLIC DRAMA, in which Christianity is the entire context for the drama, and the empire is no longer one but divided so that the conflict is between the vicarius Christi of the Christian church and the vicarius Pilati of the Christian state;

4. PROTESTANT DRAMA, in which even the Christian church is divided, so that the conflict is between the vicarius Christi of the truth of the church, usually expressed in the individual conscience, and the vicarius Pilati of the tradition of the church; and

5. REVOlUTIONARY DRAMA, in which the vicarius Christi is now whoever stands for a truth so radical it loses its Christian origins and the vicarius Pilati is whoever stands for the established order against this truth - so here for the first time the conflict is one in which Christianity is opposed to the vicarius Christi, and associated wholly with authority rather than with truth, in such a way that it might not even feature in the drama at all, once the vicarius Christi and the vicarius Pilati come into conflict over the secular truth.

Most historical plays fit into one of these categories, although some include elements from several. It is not necessary to make a long list. This Way to the Tomb and Caritas are instances of the first, although Caligula, The Master of Santiago and The Hidden King - which like This Way to the Tomb is an unknown masterpiece, worthy of being classed with Murder in the Cathedral - offer interesting variations. Instances of the second are the plays of Ibsen, Sayers and Arden and D'Arcy, which fuse the vicarius Christi and vicarius Pilati in the emperor, and also plays like The Royal Hunt of the Sun, The Golden Country and The Island of the Mighty which deal with the encounter of Christian and pagan worlds. Instances of the third are all the plays involving Becket and Langton. Instances of the 
fourth - which has some claim to be the classic form of modern historical drama - are Saint Joan, Luther, A Man For All Seasons, The Devils and The Jesuit. Instances of the fifth are Danton's Death, Lucifer and the Lord, The Life of Galileo, Marat/Sade, Tom Paine and Light Shining in Buckinghamshire, although here the heroes are sometimes murdered meaninglessly because they have been abandoned by their own revolution - as Danton and Marat are - or, even worse, left to moulder - as Galileo, Paine and the Ranters are - because their truths were not worth martyrdom.

Modern historical drama reaches its climax when the vicarius Christi encounters the vicarius Pilati, and a decision has to be made about what is to be done with truth. A secular truth is an odd truth, which gestures at infinite space: but if the truth is 'crucifixion-resurrection' then the drama is brought to a point. The vicarius Pilati argues that truth is horizontal; the vicarius Christi that it is vertical. And we get the classic encounters between church and conscience, or tradition and scripture. In the sixth scene of Saint Joan, for instance, the conflict is between church and conscience:

JOAN. My voices do not tell me to disobey the Church; but God must be served first.

CAUCHON. And you, and not the Church, are to be the judge?

JOAN. What other judgement can I judge by but my own?

And in the fourth scene of the second act of Luther it is between tradition and scripture:

MARTIN. I rest my case entirely on Holy Scriptures.

CAJETAN. The Pope alone has power and authority over all those things.

MARTIN. Except Scripture.

CAJETAN. Including Scripture.

This is the sort of tension which is wholly lost as modern historical drama, through its adoption of the secular truths of revolutionary plays, drifts into postmodern historical drama. This is the drama in which the truth of 'crucifixion-resurrection' is just one of many truths which are treated as if the only real truth is that there is no such truth. In this form 
of drama we hear a vulgar version of the what is expressed by Talbot in The Maid of Orleans, by Empedocles in Arnold's lyric Empedocles at Etna (1852), ${ }^{81}$ and by almost everyone in Hardy's epic Dynasts $(1908)^{82}-$ where Christianity is seen 'in dim pathetical and brief parentheses'. When this voice is heard, as it is heard in the unambiguous postmodern historical drama of Bond, Barnes and Brenton, we have drama written from the point of view of those who mocked Christ. ${ }^{83}$ The historical drama for a century after Ibsen was still conscious that history was a repository of truth and not simply a syllabus of errors. If history is a syllabus of errors, then there is nothing for us to do but to make good comedy out of it, or fall into despair, or simply give up drama altogether. It may be that all the turbulence of historical plays in the last four decades - all the rectal spasm and rictus smile of Rudkin's Triumph of Death (1981) - indicates that dramatists have for some time been unable to distinguish regret about the loss of the truth from defiance about the determination to lose it. ${ }^{84}$ 'If Christ be not raised', said Paul, 'your faith is in vain. ${ }^{85}$ And if we no longer respect the fact that men in former times had faith, then historical drama is dead. For we can no longer 'experience a happening of long ago as if it is actually taking place in the present and has direct reference to the present'.

\section{BILKENT UNIVERSITY, ANKARA}

\footnotetext{
${ }^{81}$ Matthew Arnold, 'Empedocles on Etna', The Complete Poems ed. Kenneth Allott (London: Longman, 1979), p. 154-207.

82 Thomas Hardy, The Dynasts: An Epic-Drama of the War with Napoleon (London: Macmillan, 1978).

83 The first completely postmodern historical drama was Edward Bond, Early Morning (1968) in Plays 1 (London: Methuen, 1977), which involved no religion. See the equally irreligious play by Howard Brenton, The Romans in Britain (London: Eyre Methuen, 1980). For how postmodern historical plays deal with religion see Howard Brenton, Wesley in Plays for Public Places, (London: Eyre Methuen, 1972) and Barnes, The Bewitched. ${ }^{84}$ David Rudkin, The Triumph of Death (London: Methuen, 1981). Rudkin recalls that while he wrote Triumph of Death he wanted to write a 'binary companion piece' on 'the trial and execution of Jesus'. But of course it was impossible for a dramatist of his tendencies to do this. 'I decided I wasn't really ready yet to achieve my concept,' he wrote in 1993, 'so I laid the draft aside, and haven't yet returned to it. See Ian Rabey, David Rudkin: Sacred Disobedience: An Expository Study of His Drama 1959-96 (Amsterdam: Harwood, 1997) p. 103.

851 Corinthians 15.17.
} 